\title{
PEMODELAN ANGKA KEMATIAN IBU DI INDONESIA DENGAN PENDEKATAN GEOGRAPHICALLY WEIGHTED POISSON REGRESSION
}

\author{
Rivan Destyanugraha \\ Robert Kurniawan \\ Jurusan Komputasi Statistik, Sekolah Tinggi IImu Statistik (STIS) \\ e-mail:12.7351@stis.ac.id
}

\begin{abstract}
Maternal Mortality Rate (MMR) is one of the important indicators of a country's health development and is one of the targets of achieving Sustainable Development Goals (SDGs). This study aims to develop a model on the relationship of MMR with provincial health development variables using the Geographically Weighted Poisson Regression (GWPR) method; as well as mapping the model to the provincial map. Estimation of model parameters using PODES data for 2011 and the projected health and projection profile of 2010-2013. The obtained model consists of four variables that influence the number of maternal deaths: (1) the ratio of health facilities, (2) the ratio of midwives, (3) the percentage of deliveries assisted by health personnel, and (4) the percentage of pregnant women received Fe tablets. The mapping of the four variables into the provincial map yields three groups of regions with different levels of significance of variables. The AIC value and the GWPR model deviance are lower than Poisson regression, indicated that the AKI model with GWPR is better than Poisson regression.
\end{abstract}

Keywords: GWPR, maternal mortality, modeling, Poisson regression.

\begin{abstract}
ABSTRAK
Angka Kematian Ibu (AKI) merupakan salah satu indikator penting pembangunan kesehatan suatu negara dan menjadi salah satu target pencapaian Sustainable Development Goals (SDGs). Penelitian ini bertujuan menyusun model hubungan AKI dengan variabel-variabel pembangunan kesehatan provinsi menggunakan metode Geographically Weighted Poisson Regression (GWPR) dan memetakan model tersebut ke dalam peta provinsi. Estimasi parameter model menggunakan data PODES tahun 2011 dan profil kesehatan dan proyeksi penduduk tahun 2010-2013. Model yang diperoleh terdiri dari empat variabel yang mempengaruhi jumlah kematian ibu, yaitu rasio sarana kesehatan, rasio bidan, persentase persalinan ditolong tenaga kesehatan, dan persentase ibu hamil mendapat tablet Fe. Pemetaan empat variabel tersebut ke dalam peta provinsi menghasilkan tiga kelompok wilayah dengan tingkat signifikansi variabel yang berbeda-beda. Nilai AIC dan deviance model Geographically Wighted Poisson Regression (GWPR) lebih rendah dari regresi Poisson menunjukkan bahwa model AKI dengan GWPR lebih baik dari regresi Poisson.

Kata kunci: angka kematian ibu, GWPR, pemodelan, regresi Poisson.
\end{abstract}


Negara-negara dalam Perserikatan Bangsa-Bangsa (PBB) menyusun agenda pembangunan berkelanjutan yang disebut Sustainable Development Goals (SDGs) pada tanggal 21 Oktober 2015 sebagai upaya menciptakan dunia yang bebas dari kemiskinan, kerusakan lingkungan, dan ketakutan. Agenda ini berisi 17 dan 169 target yang saling terkait dan tak terpisahkan (PBB, 2015). Selanjutnya agenda ini menjadi acuan pembangunan seluruh negara dengan harapan seluruh tujuan dan target dapat dicapai hingga tahun 2030.

Salah satu di antara tujuh belas tujuan SDGs tersebut adalah menjamin hidup sehat dan kehidupan yang lebih baik untuk seluruh penduduk dunia di segala umur. Tujuan ini dijabarkan ke dalam tiga belas target dan salah satu di antara target tersebut adalah mengurangi rasio kematian ibu (maternal mortality) global hingga kurang dari 70 per 100.000 kelahiran hidup (PBB,2015). Dengan demikian, kematian ibu merupakan salah satu indikator penting dalam pembangunan di bidang kesehatan suatu negara dan khususnya bagi pencapaian SDGs negara tersebut.

Badan Pusat Statistik (BPS) mendefinisikan Angka Kematian Ibu (AKI) sebagai banyaknya kematian perempuan pada saat hamil atau selama 42 hari sejak terminasi kehamilan yang disebabkan karena kehamilannya atau pengelolaannya per 100.000 kelahiran hidup (BPS, 2016). Untuk menghitung AKI tersebut, diperlukan data jumlah kematian ibu yang berupa data cacah (count data). Data cacah didefinisikan sebagai data frekuensi suatu kejadian yang dikumpulkan berdasarkan jumlah kejadian suatu peristiwa (Cameron \& Trivedi, 2013). Untuk keperluan analisis data tersebut, Agresti (2013) menyebutkan bahwa distribusi data cacah secara sederhana mengikuti distribusi Poisson sehingga data jumlah kematian ibu dapat diasumsikan mengikuti distribusi Poisson dan dapat dianalisis dengan regresi Poisson.

Masalah kematian ibu memiliki dimensi medis maupun nonmedis yang meliputi masalah sosial, ekonomi, pendidikan, dan lingkungan (Novita, Salamah \& Sutikno, 2012). Faktor-faktor yang mempengaruhi kematian ibu dapat berbeda antar wilayah. Perbedaan ini disebabkan oleh perbedaan budaya dan tradisi mengenai mitos kehamilan dan perawatannya (Qomariyah, Purnami \& Pramono, 2013). Berdasarkan fakta-fakta tersebut, terdapat hubungan antara jumlah kematian ibu dan variabel kewilayahan (spasial) antarprovinsi. Untuk mengungkap hubungan tersebut, penelitian ini menyusun model hubungan AKI dengan variabel-variabel pembangunan kesehatan provinsi menggunakan metode Geographically Weighted Poisson Regression (GWPR) dan memetakan model AKI kedalam peta provinsi. Metode ini mampu menggambarkan variasi spasial dalam hubungan antar parameter dalam model regresi (Nakaya et al., 2005). Selain itu, metode GWPR juga telah banyak digunakan dalam berbagai penelitian terkait kematian ibu untuk mengungkap variasi faktor yang mempengaruhi kejadian tersebut di berbagai wilayah, seperti yang dilakukan oleh Novita, Salamah \& Sutikno (2012) dan Qomariyah, Purnami \& Pramono (2013) yang menganalisis kematian ibu di Provinsi Jawa Timur. Azmi (2014) juga memodelkan kematian ibu dengan metode analisis GWPR untuk Provinsi Jawa Tengah dan Provinsi Jawa Timur.

Analisis regresi merupakan sebuah alat statistik yang memanfaatkan hubungan antara dua atau lebih variabel kuantitatif sehingga nilai dari salah satu variabel tersebut dapat diprediksi dari variabel lainnya (Neter, Wasserman \& Kutner, 1983). Generalized Linear Model (GLM) membedakan pemodelan regresi berdasarkan jenis dan karakteristik variabel responnya (McCullagh \& Nelder, 1989). Model regresi Poisson sering digunakan untuk jenis variabel respon berupa data cacah (Cameron \& Trivedi, 2013; Ramadhan \& Kurniawan, 2016).

Model regresi Poisson mengasumsikan bahwa regresi antara variabel respon $y_{i}$ dengan variabel $\mathbf{x}_{i}$ yang berukuran $n \times p$ berdistribusi Poisson dan independen (Cameron \& Trivedi, 2013; Saefuddin, Saepudin \& Kusumaningrum, 2013), dengan fungsi kepadatan sebagai berikut: 


$$
f\left(y_{i} \mid x_{i}\right)=\frac{e^{-\mu_{i}} y_{i} y_{i}}{y_{i} !} ; y=0,1,2, \ldots
$$

dan $\mu_{i}=\exp \left(\mathbf{x}_{i}^{\prime} \boldsymbol{\beta}\right)$ dengan $\boldsymbol{\beta}$ adalah vektor parameter regresi berdimensi $p \times 1$. Variabel $\mathbf{x}_{i}, \boldsymbol{\beta}$ dan $\mu_{i}$ bersama-sama dibentuk ke dalam model regresi Poisson berdasarkan persamaan berikut:

$$
\ln \left(\mu_{\mathrm{i}}\right)=\beta_{0}+\beta_{1} x_{i 1}+\beta_{2} x_{i 2}+\ldots+\beta_{(p-1)} x_{(p-1)}=x_{i}^{\prime} \beta
$$

dengan $p$ adalah jumlah parameter regresi.

Estimator standar untuk model regresi Poissondiperoleh dengan menggunakan metode Maximum Likelihood Estimator (MLE) yaitu dengan memaksimumkan fungsi log-likelihood berikut:

$$
L(\boldsymbol{\beta})=\sum_{i=1}^{n}\left\{y_{i} \mathbf{x}_{i}^{\prime} \boldsymbol{\beta}-\exp \left(\mathbf{x}_{i}^{\prime} \boldsymbol{\beta}\right)-\ln y_{i} !\right\} \text {. }
$$

Untuk memperoleh maksimum log-likelihood, persamaan (3) diturunkan terhadap $\beta$ sehingga menghasilkan MLE Poisson $\widehat{\beta}$ sebagai solusi orde pertama dengan persamaan berikut:

$$
\sum_{i=1}^{n}\left(y_{i}-\exp \left(\mathbf{x}_{\mathrm{i}}^{\prime} \boldsymbol{\beta}\right)\right) \mathbf{x}_{\mathrm{i}}=0 .
$$

Persamaan (4) tidak linier dalam parameternya, solusi terhadap persamaan tersebut diperoleh dengan metode iterasi Newton-Rhapson atau Iteratively Reweighted Least Square sehingga persamaan tersebut konvergen.

Metode Geographically Weighted Poisson Regression (GWPR) sebagai salah satu jenis metode regresi bersyarat kerne/ yang digunakan untuk mengestimasi keragaman spasial dalam parameter regresi Poisson (Fotheringham, Brunsdon \& Charlton, 2002; Nakaya et al, 2005). Koefisien GWPR dapat diestimasi dengan menyusun model regresi Poisson dengan fungsi likelihood yang telah diberi penimbang geografis dan penimbang tersebut diberikan melalui fungsi kernel yang berpusat di vektor koordinat wilayah $\left(\mathrm{u}_{\mathrm{i}}, \mathrm{v}_{\mathrm{i}}\right)$.

Langkah-langkah yang diperlukan untuk mengestimasi koefisien GWPR adalah sebagai berikut (Saefuddinet al, 2013; Fotheringham et al, 2002; Nakaya et al, 2005):

1. Membuat fungsi likelihood distribusi Poisson dari sejumlah $n$ variabel respon $\left(y_{i} \sim \operatorname{Poisson}\left(\mu\left(x_{i}, \beta\right)\right)\right.$, yaitu:

$$
\begin{aligned}
& L(\boldsymbol{\beta})=\prod_{i=1}^{n} \frac{\exp \left(-\mu\left(\mathbf{x}_{i}, \boldsymbol{\beta}\right)\right)\left(\mu\left(\mathbf{x}_{i}, \boldsymbol{\beta}\right)\right)^{y_{i}}}{y_{i} !} \\
& \text { dengan } \mu\left(\mathbf{x}_{i}, \boldsymbol{\beta}\right)=\exp \left(\mathbf{x}_{i}^{\prime} \boldsymbol{\beta}\right) .
\end{aligned}
$$

2. Memaksimalkan fungsi log-likelihood dalam persamaan (5)menjadi

$$
\ln L(\boldsymbol{\beta})=-\sum_{i=1}^{n} \exp \left(\mathbf{x}_{i}^{\prime} \boldsymbol{\beta}\right)+\sum_{i=1}^{n} y_{i}\left(\mathbf{x}_{i}^{\prime} \boldsymbol{\beta}\right)-\sum_{i=1}^{n} \ln y_{i} !
$$

3. Persamaan (6) dapat dituliskan kembali dalam bentuk penimbang observasi $w_{i j}$ sebagai berikut : $\ln ^{*} L\left(\beta\left(u_{i}, v_{i}\right)\right)=\left\{\ln L\left(\beta\left(u_{i}, v_{i}\right)\right)\right\} w_{i j}\left(u_{i}, v_{i}\right)$

4. Menurunkan secara parsial persamaan (7) terhadap parameter dalam $\boldsymbol{\beta}^{\prime}\left(\mathrm{u}_{\mathrm{i}}, \mathrm{v}_{\mathrm{i}}\right)$ dan hasilnya disamakan dengan nol:

$$
\frac{\partial \ln ^{*} L\left(\beta\left(u_{i}, v_{i}\right)\right)}{\partial \beta^{\prime}\left(u_{i}, v_{i}\right)}=\left\{-\sum_{i=1}^{n} x_{i} \exp \left(\mathbf{x}_{i}^{\prime} \beta\left(u_{i}, v_{i}\right)\right)+\sum_{i=1}^{n} y_{i} x_{i}\right\} w_{i j}\left(u_{i}, v_{i}\right)=0
$$

Persamaan (8) ini bersifat berulang atau disebut juga iterative hingga nilai maksimum diperoleh. 
5. Masalah memaksimumkan persamaan (8) dapat diselesaikan dengan prosedur local Fisher scoring, salah satu bentuk dari Iteratively Reweighted Least Squares (IRLS). Menurut prosedur ini, penghitungan matriks weighted least squares $\mathbf{W}$ harus diulang untuk memperbarui estimasi nilai parameter hingga nilainya konvergen:

$\boldsymbol{\beta}^{(l+1)}\left(u_{i}, v_{i}\right)=\left(X^{\prime} \mathbf{W}\left(u_{i}, v_{i}\right) \mathbf{A}\left(u_{i}, v_{i}\right)^{(l)} \mathbf{X}\right)^{-1} \mathbf{X}^{\prime} \mathbf{W}\left(u_{i}, v_{i}\right) \mathbf{A}\left(u_{i}, v_{i}\right)^{(l)} \mathbf{z}\left(u_{i}, v_{i}\right)^{(l)}$

dengan $\boldsymbol{\beta}^{(l+1)}$ adalah vektor dari estimasi parameter lokal khusus untuk wilayah $i$ dan pangkat $(I+1)$ menandakan jumlah iterasi. Vektor dari estimasi parameter lokal khusus untuk wilayah $i$ ketika iterasi ke I didefinisikan sebagai berikut:

$\boldsymbol{\beta}^{(I)}\left(\mathrm{u}_{\mathrm{i}}, \mathrm{v}_{\mathrm{i}}\right)=\left(\boldsymbol{\beta}_{0}{ }^{(I)}\left(\mathrm{u}_{\mathrm{i}}, \mathrm{v}_{\mathrm{i}}\right), \boldsymbol{\beta}_{1}{ }^{\left({ }^{(I)}\right.}\left(\mathrm{u}_{\mathrm{i}}, \mathrm{v}_{\mathrm{i}}\right), \ldots, \boldsymbol{\beta}_{\mathrm{k}}{ }^{(I)}\left(\mathrm{u}_{\mathrm{i}}, \mathrm{v}_{\mathrm{i}}\right)\right)^{\prime}$

$\mathbf{X}$ adalah matriks desain dan $\mathbf{X}$ 'merupakan matriks transpose dari $\mathbf{X}$.

$X=\left[\begin{array}{cccc}1 & x_{11} & \ldots & x_{1 k} \\ 1 & x_{21} & \ldots & x_{2 k} \\ \cdot & \cdot & \ldots & \cdot \\ 1 & x_{n 1} & \ldots & x_{n k}\end{array}\right]$

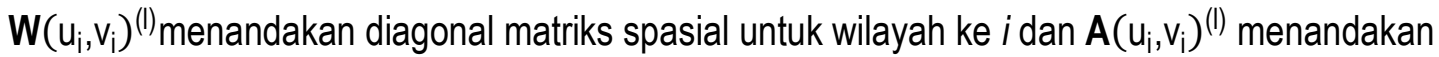
matriks penimbang varians terkait dengan Fisher scoring untuk setiap wilayah $i$ :

$\mathbf{A}\left(\mathrm{u}_{\mathrm{i}}, \mathrm{v}_{\mathrm{i}}\right)^{(I)}=\operatorname{diag}\left[\hat{\mathrm{y}}_{1} \boldsymbol{\beta}^{(\mathrm{I})}\left(\mathrm{u}_{\mathrm{i}}, \mathrm{v}_{\mathrm{i}}\right), \hat{\mathrm{y}}_{2} \boldsymbol{\beta}^{(\mathrm{I})}\left(\mathrm{u}_{\mathrm{i}}, \mathrm{v}_{\mathrm{i}}\right), \ldots, \hat{\mathrm{y}}_{\mathrm{n}} \boldsymbol{\beta}^{(\mathrm{l})}\left(\mathrm{u}_{\mathrm{i}}, \mathrm{v}_{\mathrm{i}}\right)\right]$

Kemudian, $\mathbf{z}\left(\mathrm{u}_{\mathrm{i}}, \mathrm{v}_{\mathrm{i}}\right)^{(1)}$ adalah vektor dari variabel respon yang telah disesuaikan. Vektor ini didefinisikan sebagai berikut:

$\mathrm{z}^{(I)}\left(\mathrm{u}_{\mathrm{i}}, \mathrm{v}_{\mathrm{i}}\right)=\left[\mathrm{z}_{1}{ }^{(\mathrm{I})}\left(\mathrm{u}_{\mathrm{i}}, \mathrm{v}_{\mathrm{i}}\right), \mathrm{z}_{2}{ }^{(I)}\left(\mathrm{u}_{\mathrm{i}}, \mathrm{v}_{\mathrm{i}}\right), \ldots, \mathrm{z}_{\mathrm{n}}{ }^{(I)}\left(\mathrm{u}_{\mathrm{i}}, \mathrm{v}_{\mathrm{i}}\right)\right]^{\prime}$

dengan mengulang prosedur iteratif ini untuk setiap titik regresi $i$, seluruh estimasi parameter lokal akan diperoleh.

6. Setelah konvergen, persamaan 9 dapat dituliskan kembali sebagai berikut:

$$
\beta\left(u_{i}, v_{i}\right)=\left(X^{\prime} W\left(u_{i}, v_{i}\right) A\left(u_{i}, v_{i}\right) X\right)^{-1} X^{\prime} W\left(u_{i}, v_{i}\right) A\left(u_{i}, v_{i}\right) z\left(u_{i}, v_{i}\right)
$$

Untuk mengetahui parameter mana saja yang yang berpengaruh secara signifikan terhadap variabel respons pada masing-masing lokasi, digunakan statistik lokal pseudo-t sebagai berikut:

$$
\mathrm{t}=\frac{\widehat{\beta_{k}}\left(u_{i}, v_{i}\right)}{\operatorname{se}\left(\widehat{\beta_{k}}\left(u_{i}, v_{i}\right)\right)} \text {. }
$$

dengan $\widehat{\beta_{\mathrm{k}}}\left(\mathrm{u}_{\mathrm{i}}, \mathrm{v}_{\mathrm{i}}\right)$ adalah penduga parameter $\beta_{\mathrm{k}}\left(u_{i}, v_{i}\right)$ dan $\operatorname{se}\left(\widehat{\beta_{\mathrm{k}}}\left(\mathrm{u}_{\mathrm{i}}, \mathrm{v}_{\mathrm{i}}\right)\right)$ merupakan penduga standard error dari penduga parameter $\beta_{\mathrm{k}}\left(u_{i}, v_{i}\right)$ yang diperoleh dari penghitungan berikut.

$$
\operatorname{se}\left(\widehat{\beta_{k}}\left(u_{i}, v_{i}\right)\right)=\sqrt{\operatorname{cov}\left(\widehat{\beta}\left(u_{i}, v_{i}\right)\right)_{k}}
$$

dengan:

$$
\operatorname{cov}\left(\widehat{\beta}\left(u_{i}, v_{i}\right)\right)=C\left(u_{i}, v_{i}\right) A\left(u_{i}, v_{i}\right)^{-1} \mathbf{C}\left(u_{i}, v_{i}\right)^{\prime},
$$




$$
\mathbf{C}\left(u_{i}, v_{i}\right)=\left(X^{\prime} W\left(u_{i}, v_{i}\right) A\left(u_{i}, v_{i}\right) X\right)^{-1} X^{\prime} W\left(u_{i}, v_{i}\right) A\left(u_{i}, v_{i}\right),
$$

$\operatorname{cov}\left(\widehat{\boldsymbol{\beta}}\left(\mathbf{u}_{i}, \mathbf{v}_{i}\right)\right)_{k}$ adalah elemen diagonal ke-k dari matriks kovarians $\operatorname{cov}\left(\widehat{\boldsymbol{\beta}}\left(\mathbf{u}_{i}, \mathbf{v}_{i}\right)\right)$, dan $\mathbf{A}\left(\mathbf{u}_{i}, \mathbf{v}_{\mathrm{i}}\right)^{-1}$ adalah invers dari matriks varians-kovarians Poisson seperti pada persamaan (12). Statistik lokal pseudo-t tersebut mendekati distribusi normal baku dan suatu variabel dikatakan signifikan di suatu wilayah jika nilai |t| variabel tersebut lebih besar dari nilai tabel normal pada tingkat a tertentu.

Setiap pembentukan model GWPR diperlukan suatu penimbang setiap data observasi untuk mengestimasi setiap parameter dalam model statistik lokal dari setiap wilayah. Penimbang tersebut dibentuk dalam matriks penimbang $\mathbf{W}_{(\mathrm{i})}$ atau dinotasikan juga $\mathbf{W}\left(\mathrm{u}_{\mathrm{i}}, \mathrm{v}_{\mathrm{i}}\right)$ yang memiliki bentuk:

$$
\mathbf{W}_{(\mathrm{i})}=\left[\begin{array}{cccc}
\mathrm{W}_{\mathrm{i} 1} & 0 & \ldots & 0 \\
0 & \mathrm{~W}_{\mathrm{i} 2} & \ldots & 0 \\
. & . & & . \\
0 & 0 & \ldots & \mathrm{W}_{\text {in }}
\end{array}\right]
$$

dengan $w_{\text {in }}$ adalah penimbang yang diberikan untuk titik data $n$ dalam penyusunan model untuk wilayah $i$. Untuk menentukan penimbang $\mathbf{W}_{(\mathrm{i})}$ tersebut, digunakan fungsi kernel atau disebut juga distance-decay functions (Fotheringham, Brunsdon \& Charlton, 2002).

Fungsi kernel memberi nilai penimbang pada matriks $\mathbf{W}_{(\mathrm{i})}$ berdasarkan kedekatan suatu titik regresi ke-i terhadap titik lokasi data di sekitar $i$. Kedekatan ini dihitung berdasarkan jarak yang diukur menurut koordinat masing-masing titik. Terdapat empat fungsi kernel yang umum digunakan dalam menentukan nilai penimbang tersebut, yaitu fungsi kernel Gaussian, Exponential, Bisquare, dan Tricube (Fotheringham, Brunsdon \& Charlton, 2002; Nakaya et al, 2005; Yasin, 2011).

1. Fungsi kernel Gaussian

$$
\mathrm{w}_{\mathrm{ij}}=\exp \left(-\frac{1}{2}\left(\frac{d_{\mathrm{ij}}}{\mathrm{b}}\right)^{2}\right)
$$

2. Fungsi kernel Exponential

$$
\mathrm{w}_{\mathrm{ij}}=\exp \left(-\frac{\mathrm{dij}_{\mathrm{ij}}}{\mathrm{b}}\right)
$$

3. Fungsi kernel Bisquare

$$
w_{i j}=\left\{\begin{array}{c}
{\left[1-\left(\frac{d_{i j}}{b}\right)^{2}\right]^{2}, d_{i j} \leq b} \\
0, d_{i j}>b
\end{array}\right.
$$

4. Fungsi kernel Tricube

$$
w_{i j}=\left\{\begin{array}{c}
{\left[1-\left(\frac{d_{i j}}{b}\right)^{3}\right]^{3}, d_{i j} \leq b} \\
0, d_{i j}>b
\end{array}\right.
$$

dengan $d_{i j}$ adalah jarak antara titik regresi dan data pengamatan yang dihitung dengan jarak Euclidean yang dirumuskan dalam persamaan berikut:

$$
d_{i j}=\sqrt{\left(u_{i}-u_{j}\right)^{2}+\left(v_{i}-v_{j}\right)^{2}}
$$


dan $b$ dijelaskan sebagai bandwidth.

Secara garis besar, fungsi kernel terbagi menjadi dua skema yaitu skema fixed dan adaptive. Skema penimbang fixed menghasilkan besaran penimbang yang tetap antar titik regresi sehingga mengabaikan tingkat kepadatannya di sekitar titik tersebut. Hal ini akan menimbulkan permasalahan ketika titik data pengamatan sangat padat di beberapa titik atau sebaliknya menyebar sehingga diperlukan fungsi kernel yang memberi penimbang yang menyesuaikan dengan sebaran titik datanya atau yang kemudian disebut skema adaptive.

Nilai penimbang yang diberikan fungsi kerne/ sangat bergantung pada nilai bandwidth. Bandwidth dapat dianalogikan seperti radius suatu lingkaran. Sebuah titik data yang berada dalam radius atau bandwidth lingkaran tersebut dianggap memberi pengaruh dalam pembentukan model lokal titik regresi yang menjadi pusat lingkaran tersebut. Nilai bandwidth ini sangat sensitif terhadap proses estimasi model lokal. Nilai bandwidth yang terlalu besar menyebabkan makin banyak pengamatan yang berada dalam radius bandwidth tersebut sehingga menyebabkan bias yang besar karena model yang diperoleh terlampau halus (oversmoothing). Sebaliknya, nilai bandwidth yang terlalu kecil menyebabkan makin sedikit pengamatan yang berada dalam radius bandwidth tersebut sehingga varians yang dihasilkan model semakin besar dan model menjadi kasar (undersmoothing) (Novita, Salamah \& Sutikno, 2012).

Karena terdapat trade-off antara bias dan varians pada pemilihan nilai bandwidth, pemilihan nilai bandwidth yang optimum dapat dilakukan dengan indikator pemilihan model Akaike Information Criterion corrected (AICc) yang merupakan penyesuaian dari AIC terhadap nilai derajat bebas dari data (Nakaya et al, 2005). AlCc adalah persamaan berikut:

$$
\begin{aligned}
\operatorname{AICc}(b) & =D(b)+2 K(b)+2 \frac{K(b)(K(b)+1)}{N-K(b)-1} \\
& =A I C(b)+2 \frac{K(b)(K(b)+1)}{N-K(b)-1}
\end{aligned}
$$

dengan $N$ menyatakan jumlah data yang dianalisis, $\mathrm{K}$ adalah jumlah parameter, dan $\mathrm{D}(\mathrm{b})$ adalah nilai deviance. Nilai bandwidth optimum diperoleh ketika nilainya menghasilkan model dengan nilai indikator AICc terkecil. Sedangkan nilai deviance seperti yang didefinisikan oleh McCullagh dan Nelder (1989), sebagai berikut:

$D(b)=\sum_{i}^{N}\left(y_{i} \log \hat{y}_{i}\left(\boldsymbol{\beta}\left(\boldsymbol{u}_{i}\right), b\right) / y_{i}+y_{i}-\hat{y}_{i}\left(\boldsymbol{\beta}\left(\boldsymbol{u}_{i}\right), b\right)\right)$

Fotheringham, Brunsdon \& Charlton. (2002) menjelaskan salah satu cara melihat kesesuaian suatu model dengan menggunakan kriteria AIC atau AICc. Seperti yang telah dijelaskan dalam persamaan (25), dalam menghitung AIC atau AICc digunakan juga nilai deviance seperti pada persamaan (26), sehingga secara tidak langsung nilai tersebut dapat digunakan dalam membandingkan kesesuaian model seperti yang digunakan dalam Nakaya et al. (2005).

Data yang digunakan untuk kasus penelitian ini adalah data yang bersumber dari tiga publikasi, publikasi hasil Potensi Desa (PODES) tahun 2011 oleh BPS, publikasi Profil Kesehatan Indonesia oleh Kementerian Kesehatan, dan publikasi Proyeksi Penduduk Indonesia Tahun 20102035 oleh BPS, Badan Perencanaan Pembangunan Nasional (BAPPENAS), dan United Nations Population Fund (UNFPA). Variabel yang digunakan dalam model terdiri dari satu variabel respon dan lima variabel bebas. Sebagai variabel respon adalah jumlah kematian ibu per 100.000 perempuan usia 15 tahun ke atas $(Y)$. Sebagai variabel-variabel bebas adalah rasio sarana kesehatan per 100.000 penduduk (X1), rasio bidan per 100.000 penduduk (X2), persentase cakupan 
kunjungan K4 ibu hamil (X3), persentase persalinan ditolong tenaga kesehatan (X4), dan persentase ibu hamil mendapat tablet Fe (X5). Variabel-variabel ini mengacu kepada penelitian Harahap (2015), tetapi dalam penelitian ini dilakukan evaluasi model GWPR pada delapan fungsi kernel yang berbeda. berikut:

Proses analisis data menggunakan software $\mathrm{R}$, dengan langkah-langkah analisis sebagai

1. Menyusun deskripsi provinsi berdasarkan variabel penelitian menggunakan peta tematik Indonesia yaitu mendeskripsikan variabel $Y$ dan variabel bebas dari sudut kewilayahannya.

2. Mendeteksi kasus multikolinieritas regresi Poisson menggunakan nilaiVariance Inflation Factor (VIF), yaitu mengeluarkan satu per satu variabel dari model yang memiliki nilai VIF lebih dari 5 (Rogerson, 2001).

3. Menguji asumsi keragaman spasial dari data kematian ibu dengan uji Breusch-Pagan yang dibandingkan dengan tabel distribusi $x^{2}$.

4. Menganalisis dengan metode regresi Poisson.

a. Penaksiran parameter model regresi Poisson.

b. Menguji signifikansi parameter model regresi Poisson, menggunakan statistik uji Z.

c. Menghitung nilai AIC dan deviance model regresi Poisson.

5. Menganalisis dengan metode GWPR.

a. Menghitung jarak Euclidean antar provinsi berdasarkan letak koordinat geografis titik tengah provinsi tersebut.

b. Menentukan nilai bandwidth optimum berdasarkan kriteria AICc minimum.

c. Menghitung matriks penimbang spasial dengan menggunakan fungsi-fungsi kernel yang berbeda.

d. Menaksir parameter model GWPR dengan metode MLE dengan metode iterasi IRLS.

e. Menguji signifikansi parameter model regresi GWPR secara parsial di setiap provinsi menggunakan statistik lokal pseudo $t$ sehingga diperoleh variabel mana yang signifikan pada provinsi tersebut.

f. Menghitung nilai AIC dan deviance model GWPR.

6. Perbandingan model regresi Poisson dengan model GWPR menggunakan nilai AIC dan deviance masing-masing model. Model yang lebih baik adalah model yang memiliki nilai AIC dan deviance paling kecil.

\section{HASIL DAN PEMBAHASAN}

\section{Angka Kematian Ibu dan Kondisi Faktor-faktornya}

Sebaran jumlah kematian ibu per 100.000 wanita usia 15 tahun ke atas di Indonesia pada tahun 2011 disajikan pada Gambar 1. Jumlah kematian ibu tertinggi di Indonesia tahun 2011 sebagian besar berada di wilayah timur Indonesia dengan provinsi Papua memiliki jumlah kematian ibu tertinggi (88 kematian ibu per 100.000 wanita usia 15 tahun ke atas). Sementara itu, provinsi Sumatera Barat dan Bali memiliki jumlah kematian ibu terendah dengan angka 3 kematian ibu per 100.000 wanita usia 15 tahun ke atas. 


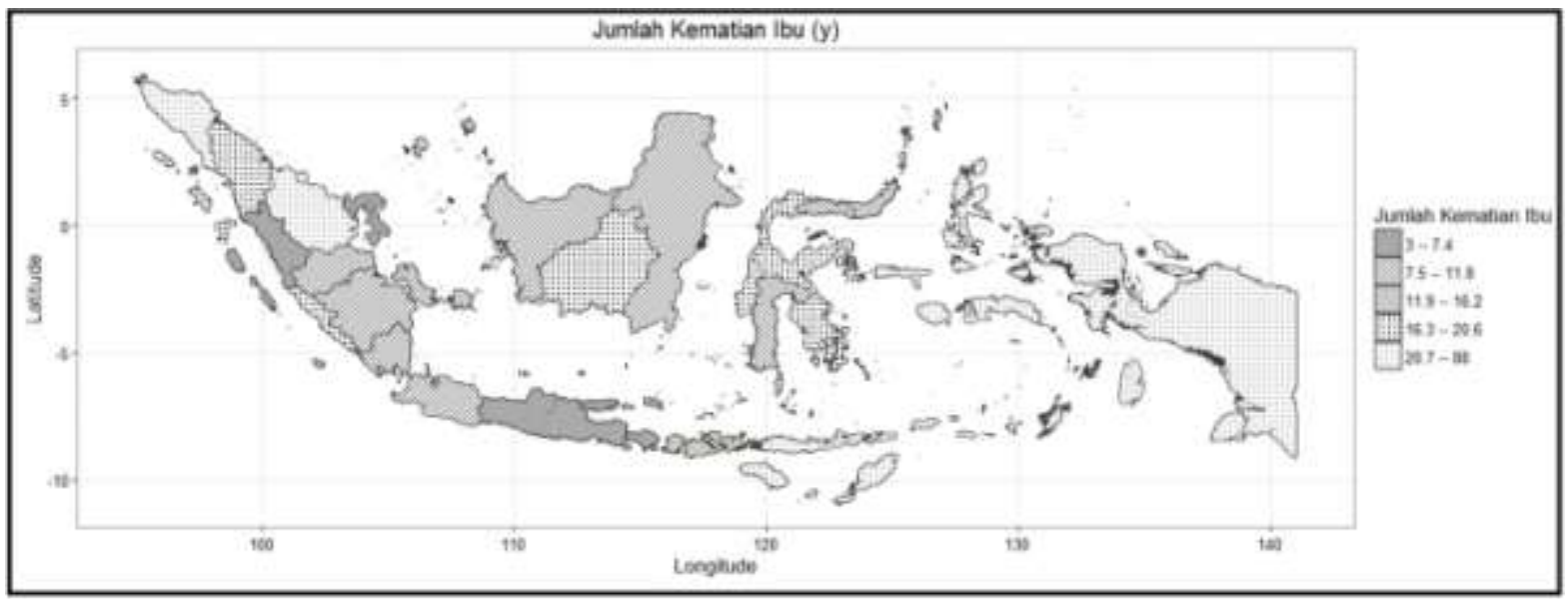

Gambar 1. Pemetaan jumlah kematian ibu per 100.000 wanita usia 15 tahun ke atas tiap provinsi di Indonesia tahun 2011

Gambar 2 menunjukkan kondisi rasio sarana kesehatan per 100.000 penduduk (X1) di tiap provinsi di Indonesia tahun 2011 sangat bervariasi. Namun terlihat hanya 7 provinsi yang memiliki rasio sarana kesehatan yang sangat tinggi hingga mendekati 1 . Hal ini menunjukkan jumlah sarana kesehatan yang ada belum mampu mengimbangi jumlah penduduk di sebagian besar provinsi di Indonesia tahun 2011 sehingga dapat dikatakan belum memadai untuk menunjang pelayanan kesehatan terutama terhadap ibu hamil dari segi jumlah.

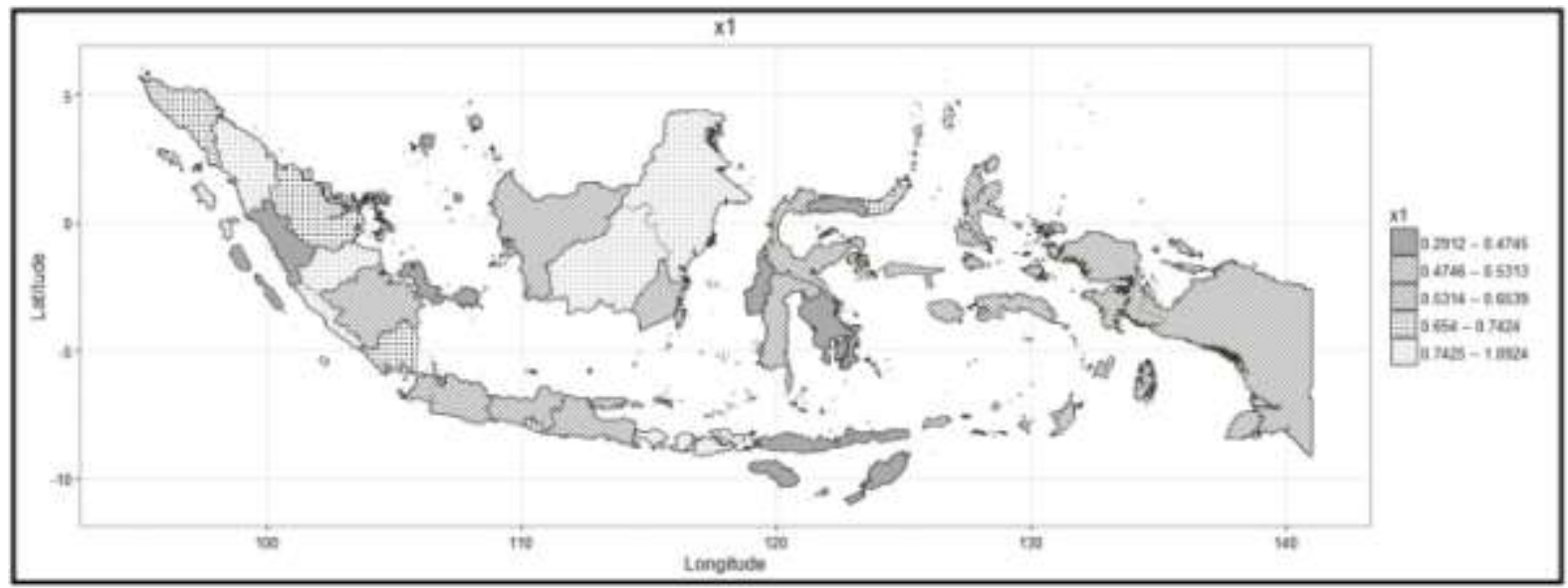

Gambar 2. Pemetaan rasio sarana kesehatan per 100.000 penduduk tiap provinsi di Indonesia tahun 2011 


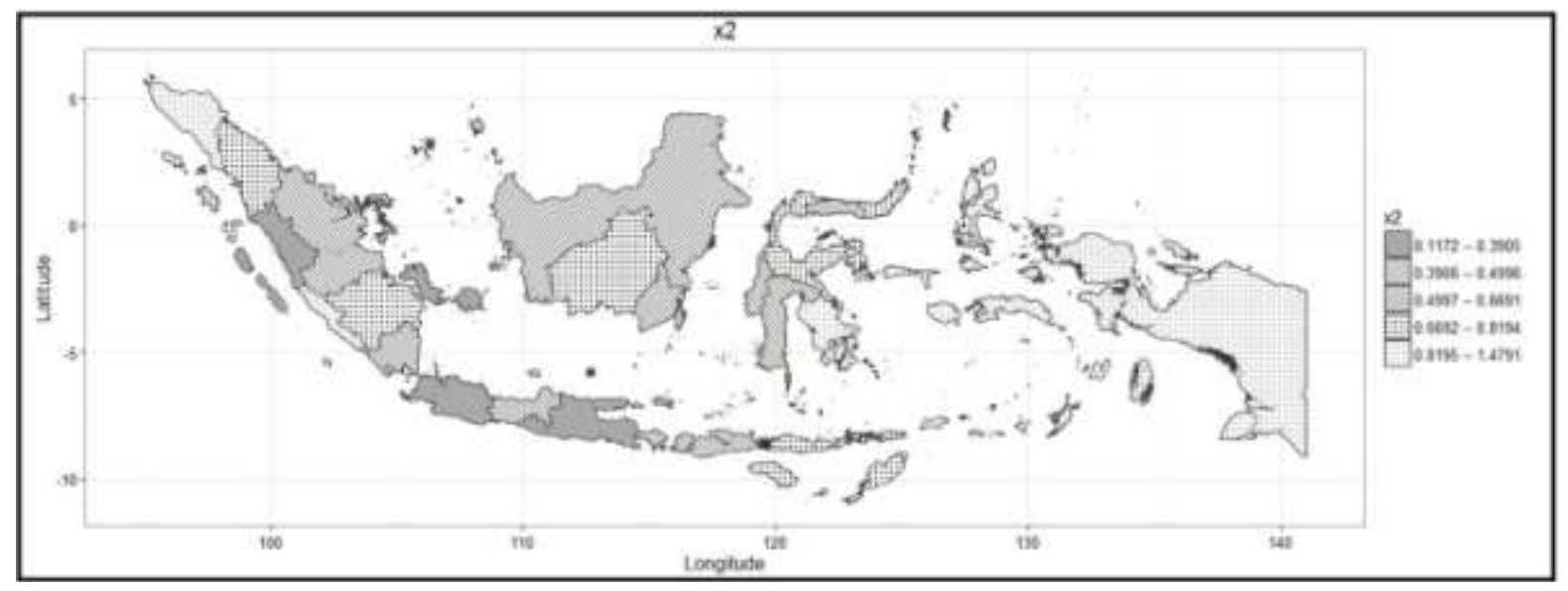

Gambar 3. Pemetaan rasio bidan per 100.000 penduduk tiap provinsi di Indonesia tahun 2011

Gambar 3 menunjukkan kondisi rasio bidan per 100.000 penduduk (X2) di tiap provinsi di Indonesia tahun 2011 sangat bervariasi. Variabel ini menunjukkan ketersediaan bidan dalam melayani kesehatan ibu di tiap provinsi per 100.000 penduduk. Dapat dilihat daerah yang memiliki jumlah kematian ibu yang tinggi seperti di provinsi Nanggroe Aceh Darussalam (NAD) memiliki rasio bidan yang sangat tinggi sebesar 1,4791, tetapi faktor ini belum ditunjang oleh kelengkapan sarana dan prasarana penunjang seperti alat-alat kesehatan maupun transportasi sehingga bidan pun kesulitan dalam memberikan pelayanan yang maksimal bagi ibu hamil di provinsi tersebut.

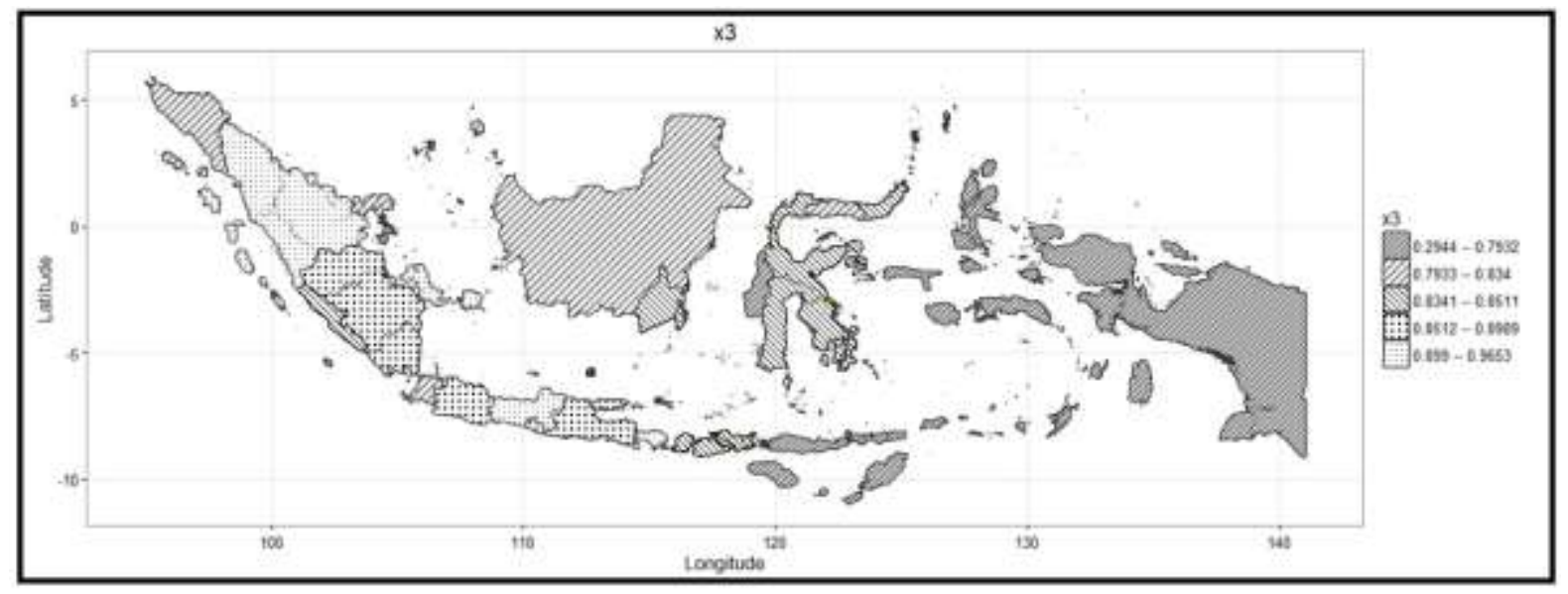

Gambar 4. Pemetaan persentase cakupan kunjungan ibu hamil (K4) tiap provinsi di Indonesia tahun 2011

Gambar 4 menunjukkan kondisi persentase cakupan kunjungan ibu hamil (K4) (X3) di tiap provinsi di Indonesia tahun 2011 bervariasi disetiap provinsi. K4 yang dimaksud merupakan kunjungan keempat ibu hamil ke petugas kesehatan sesuai dengan yang sudah dijadwalkan. Variabel ini dapat menunjukkan tingkat kesadaran kesehatan dari ibu hamil karena pemeriksaan berkala bagi ibu hamil berguna dalam memantau kesehatan ibu maupun bayi yang sedang dikandungnya. Kemudian dapat dilihat bahwa wilayah Indonesia bagian timur memiki persentase 
cakupan kunjungan terkecil dibandingkan dengan wilayah lain pada tahun 2011. Hal ini menandakan sebagian besar kehamilan pada ibu hamil di wilayah tersebut tidak terpantau kesehatannya sehingga peluang kematian ibu semakin besar.

Gambar 5 menunjukkan kondisi persentase persalinan ditolong tenaga kesehatan (X4) di tiap provinsi di Indonesia tahun 2011 sangat bervariasi. Dapat dilihat di provinsi Papua memiliki persentase yang paling kecil dibandingan wilayah lain sebesar 0,393 . Penanganan yang minim oleh tenaga kesehatan terhadap kelahiran di wilayah tersebut mendorong jumlah kematian ibu yang tinggi. Sementara itu, provinsi Jawa Barat yang memiliki persentase persalinan ditolong tenaga kesehatan yang paling besar $(1,0)$ mampu meminimkan jumlah kematian ibu pada tahun 2011. Dengan demikian, persalinan ditolong tenaga kesehatan dapat dikatakan memengaruhi secara negatif atau berlawanan terhadap jumlah kematian ibu di tiap provinsi.

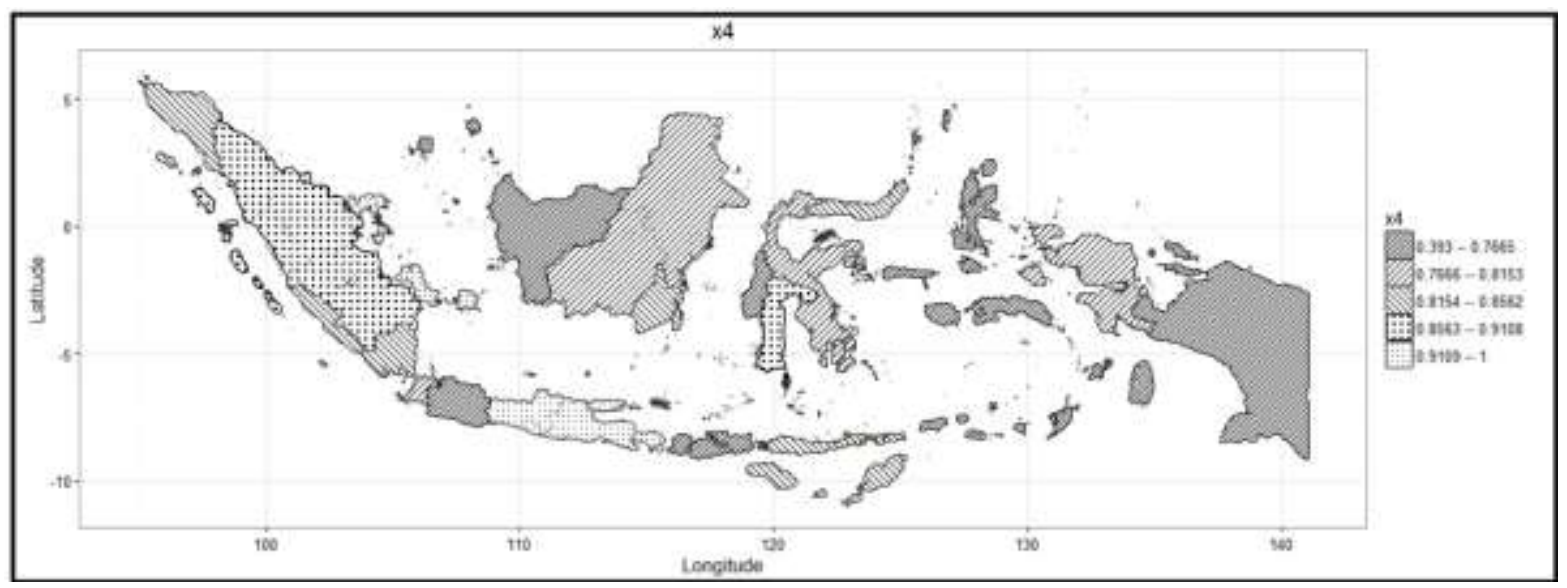

Gambar 5. Pemetaan persentase persalinan ditolong tenaga kesehatan tiap provinsi di Indonesia tahun 2011

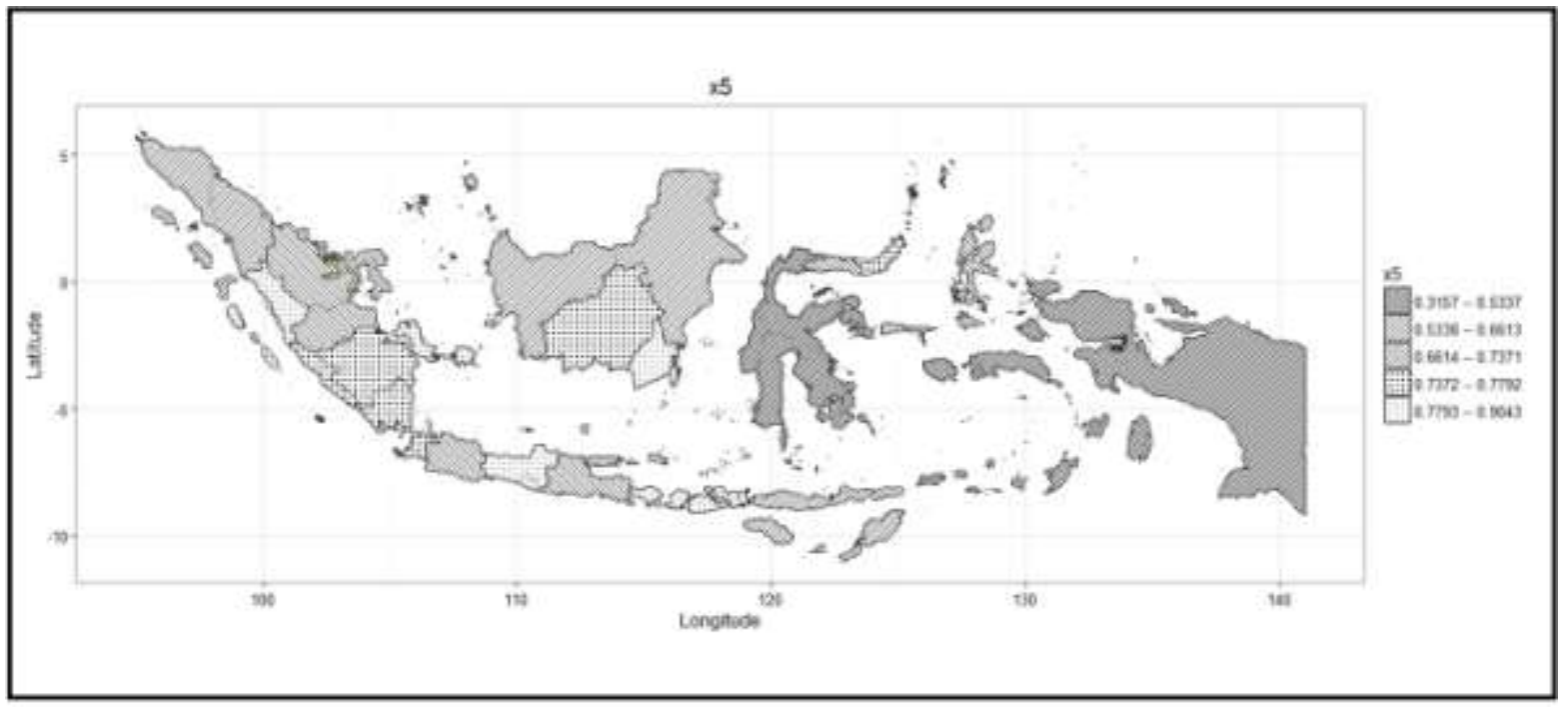

Gambar 6. Pemetaan persentase ibu hamil mendapat tablet Fe tiap provinsi di Indonesia tahun 2011 
Gambar 6 menunjukkan kondisi persentase ibu hamil yang mendapat tablet zat besi (Fe) (X5) di tiap provinsi di Indonesia tahun 2011 bervariasi di tiap provinsi. Tablet Fe merupakan suplemen bagi ibu hamil untuk menangani gejala kesehatan terkait darah seperti anemia. Dapat dilihat di provinsi Papua yang memiliki jumlah kematian ibu yang tinggi juga memiliki persentase tablet Fe yang paling kecil sebesar 0,3157 . Kematian ibu yang seringkali terjadi pasca kelahiran karena kekurangan darah diduga terjadi di wilayah tersebut karena minimnya penyebaran tablet Fe pada ibu hamil di wilayah tersebut.

\section{Model Angka Kematian Ibu di Indonesia}

Pengujian asumsi non-multikolinieritas menunjukkan model dengan variabel bebas $\mathrm{X} 1, \mathrm{X} 2$, X4, dan X5, memiliki nilai VIF yang kurang dari 5.Uji Breusch-Pagan menunjukkan nilai statistik uji BP sebesar 15,09 dan nilai $p$-value sebesar 0,004518 . Nilai $p$-value ini kurang dari $\alpha=0,05$, yang berarti antarprovinsi memiliki keragaman yang secara statistik berbeda. Keempat variabel bebas ini selanjutnya dimodelkan dengan regresi Poisson dan GWPR.

Hasil estimasi parameter model regresi Poisson disajikan pada Tabel 1 dan Tabel 2. Pengaruh rasio sarana kesehatan per 100.000 penduduk (X1) tidak signifikan terhadap model kematian ibu di Indonesia ( $p$-value $\widehat{\beta_{1}}$ kurang dari 0,05 ). Oleh karena itu, data dimodelkan kembali menggunakan regresi Poisson dengan terlebih dahulu mengeluarkan variabel X1 yang tidak signifikan sehingga diperoleh model seperti pada Tabel 2.

Tabel 1. Model Awal Regresi Poisson untuk Kematian Ibu di Indonesia Tahun 2011.

\begin{tabular}{cccccc}
\hline Koefisien & Nilai & Standar error & Statistik uji Z & $p$-value & Signifikansi $(\alpha=0,05)$ \\
\hline$(1)$ & $(2)$ & $(3)$ & $(4)$ & $(5)$ & $(6)$ \\
\hline$\widehat{\beta_{0}}$ & 5,1253 & 0,2450 & 20,917 & $<2 \mathrm{e}-16$ & Ya \\
$\widehat{\beta_{1}}$ & $-0,1683$ & 0,3000 & $-0,561$ & 0,5747 & Tidak \\
$\widehat{\beta_{2}}$ & 1,1602 & 0,1568 & 7,397 & $1,39 \mathrm{e}-16$ & $\mathrm{Ya}$ \\
$\widehat{\beta_{4}}$ & $-3,0674$ & 0,3262 & $-9,404$ & $<2 \mathrm{e}-16$ & $\mathrm{Ya}$ \\
$\widehat{\beta_{5}}$ & $-0,8323$ & 0,3299 & $-2,523$ & 0,0116 & $\mathrm{Ya}$ \\
\hline
\end{tabular}

Tabel 2. Model Regresi Poisson untuk Kematian Ibu di Indonesia Tahun 2011 Setelah X1 Dikeluarkan Dari Model.

\begin{tabular}{ccccc}
\hline Koefisien & Nilai & Standar error & Statistik uji Z & $p$-value \\
\hline$(1)$ & $(2)$ & $(3)$ & $(4)$ & $(5)$ \\
\hline$\widehat{\beta_{0}}$ & 5,0895 & 0,2358 & 21,581 & $<2 \mathrm{e}-16^{*}$ \\
$\widehat{\beta_{2}}$ & 1,1301 & 0,1480 & 7,638 & $2,2 \mathrm{e}-16^{*}$ \\
$\widehat{\beta_{4}}$ & $-3,0783$ & 0,3254 & $-9,461$ & $<2 \mathrm{e}-16^{*}$ \\
$\widehat{\beta_{5}}$ & $-0,8918$ & 0,3130 & $-2,849$ & $0,004^{*}$ \\
\hline
\end{tabular}

Keterangan: *Signifikansi 5\% berikut:

Berdasarkan Tabel 2 dapat dituliskan persamaannya seperti pada persamaan (2) sebagai

$$
\ln \left(\hat{\mu}_{i}\right)=5,0895+1,1301 x_{i 2}-3,0783 x_{i 4^{-}} 0,8918 x_{i 5}
$$


Tabel 2 menunjukkan bahwa terdapat 3 variabel yang berpengaruh secara signifikan di seluruh provinsi, yaitu variabel rasio bidan per 100.000 penduduk (X2), persentase persalinan ditolong tenaga kesehatan (X4), dan persentase ibu hamil mendapat tablet Fe (X5). Berdasarkan model persamaan (27) dapat diinterpretasikan bahwa penambahan jumlah persalinan yang ditolong tenaga kesehatan sebesar satu persen akan menurunkan nilai jumlah kematian ibu $\left(\ln \left(\hat{\mu}_{\mathrm{i}}\right)\right)$ sebesar 3,0783 pada kondisi variabel lain konstan. Begitu juga dengan interpretasi untuk variabel lainnya dengan tanda positif menandakan variabel tersebut meningkatkan nilai $\ln \left(\hat{\mu}_{\mathrm{i}}\right)$ dan besaran peningkatannya sesuai dengan koefisiennya.

Hasil estimasi parameter model regresi GWPR disajikan pada Tabel 3 dan Tabel 4. Tabel 3 menunjukkan bahwa fungsi kernel Fixed Gaussian memberikan nilai AICc terkecil sehinga fungsi kernel tersebut yang digunakan lebih lanjut dalam pemodelan kematian ibu dengan GWPR. Selain itu, diperoleh nilai bandwidth optimum sebesar 10,4339 dalam satuan koordinat atau 1158,1629 km dalam satuan jarak, yang juga selanjutnya digunakan dalam pemodelan GWPR. GWPR merupakan metode yang menghasilkan model lokal dikarenakan dari metode ini dihasilkan model untuk masingmasing unit analisis wilayah yang digunakan. Unit analisis dalam penelitian ini adalah 33 provinsi sehingga dihasilkan 33 model untuk masing-masing provinsi. Ringkasan dari model-model tersebut dapat dilihat pada Tabel 4.

Tabel 3. Pemilihan Bandwidth Optimum dan Nilai Kriteria AICc untuk Setiap Fungsi Kernel Yang Digunakan

\begin{tabular}{clcc}
\hline Skema & \multicolumn{1}{c}{ Fungsi Kernel } & Nilai bandwidth optimum & AlCc \\
\hline \multicolumn{1}{c}{$(2)$} & \multicolumn{1}{c}{$(3)$} & $(4)$ \\
\hline \multirow{4}{*}{ Fixed } & Gaussian & 10,434 & 207,565 \\
& Exponential & 11,444 & 208,317 \\
& Bisquare & 28,047 & 207,628 \\
& Tricube & 27,435 & 208,213 \\
\hline \multirow{5}{*}{ Adaptive } & Gaussian & 21 & 218,912 \\
& Exponential & 25 & 214,652 \\
& Bisquare & 32 & 210,249 \\
& Tricube & 32 & 210,072 \\
\hline
\end{tabular}

Catatan: Skema adaptive menggunakan jumlah observasi terdekat dalam menentukan nilai bandwidth optimum.

Tabel 4. Ringkasan Koefisien Model Lokal GWPR untuk Kematian Ibu di Indonesia tahun 2011.

\begin{tabular}{cccccc}
\hline Koefisien & Minimum & Kuartil 1 & Median & Kuartil 3 & Maksimum \\
\hline$(1)$ & $(2)$ & $(3)$ & $(4)$ & $(5)$ & $(6)$ \\
\hline$\widehat{\beta_{0}}$ & 2,7890 & 4,1880 & 4,6040 & 4,7630 & 4,863 \\
$\widehat{\beta_{1}}$ & $-0,6079$ & $-0,3942$ & $-0,1336$ & 0,1977 & 1,777 \\
$\widehat{\beta_{2}}$ & 0,6461 & 1,0110 & 1,4450 & 1,8080 & 2,238 \\
$\widehat{\beta_{4}}$ & $-3,1580$ & $-2,9500$ & $-2,8840$ & $-2,7420$ & $-2,124$ \\
$\widehat{\beta_{5}}$ & $-1,0220$ & $-0,6320$ & $-0,4534$ & $-0,2887$ & $-0,171$ \\
\hline
\end{tabular}

Pengujian signifikansi parameter model GWPR dilakukan dengan menggunakan nilai statistik lokal pseudo $t$ dari model masing-masing provinsi. Uji ini untuk mengetahui faktor-faktor yang 
berpengaruh terhadap jumlah kematian ibu di setiap provinsi. Hasil pengujian setiap provinsi disajikan pada bagian lampiran.

Tabel 5. Koefisien Model Lokal GWPR untuk Kematian Ibu di Provinsi Aceh tahun 2011.

\begin{tabular}{ccccc}
\hline Koefisien & Nilai & Standar error & Statistik uji $t$ & $p$-value \\
\hline$(1)$ & $(2)$ & $(3)$ & $(4)$ & $(5)$ \\
\hline$\widehat{\beta_{0}}$ & 4,6884810 & 0,6505950 & 7,206451 & 0,0000 \\
$\widehat{\beta_{1}}$ & 0,5799014 & 0,4221696 & 1,373622 & 0,1696 \\
$\widehat{\beta_{2}}$ & 0,6460836 & 0,4147552 & 1,557747 & 0,1193 \\
$\widehat{\beta_{4}}$ & $-2,8163719$ & 0,8895915 & $-3,165916$ & $0,0015^{*}$ \\
$\widehat{\beta_{5}}$ & $-0,8223643$ & 0,7417629 & $-1,108662$ & 0,2676 \\
\hline
\end{tabular}

Keterangan: *Signifikansi $5 \%$.

Pengujian signifikansi model kematian ibu di Provinsi Aceh (Obs =1) dapat dilihat pada Tabel 5. Berdasarkan tabel tersebut, AKI di Provinsi Aceh dipengaruhi oleh X4 ( $\widehat{\beta_{4}}=-2,816 ; p$-value $=$ $0,0015)$. Koefisien model lokal GWPR kematian ibu untuk provinsi lainnya dapat di lihat pada Lampiran 1.Hasil dari pengujian untuk Provinsi Aceh dan provinsi-provinsi lainnya dapat dipetakan pada Gambar 7. Pada peta tersebut terlihat bahwa AKI di Provinsi Aceh dipengaruhi oleh variabel X4. Gambar 7 memperlihatkan tiga kelompok wilayah provinsi dengan variabel signifikan yang berbeda, yaitu kelompok 1 bertanda - dengan variabel signifikan X4, kelompok 2 bertanda $\square$ dengan variabel signifikan $\mathrm{X} 2$ dan $\mathrm{X} 4$, serta kelompok 3 bertanda $\square$ dengan variabel signifikan $\mathrm{X} 1$, $\mathrm{X} 2$, dan X4.

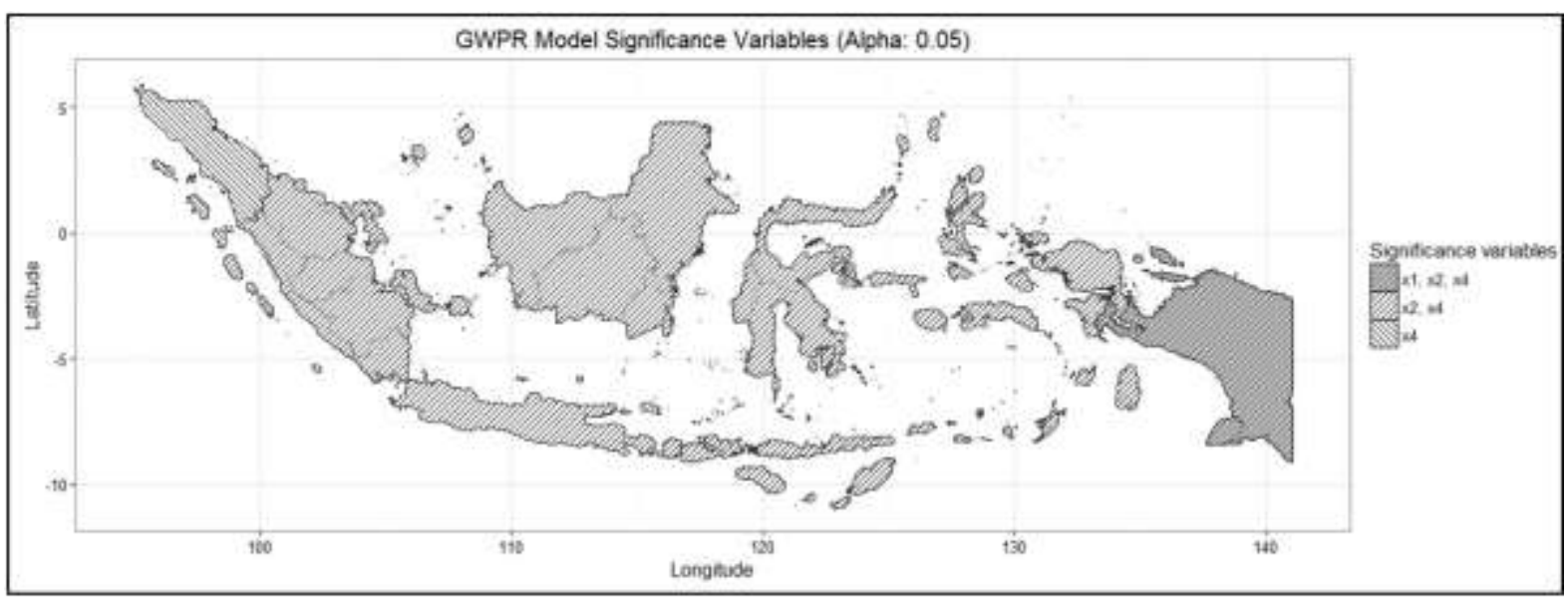

Gambar 7. Pemetaan signifikansi variabel-variabel model lokal GWPR

Berdasarkan hasil pemetaan pada Gambar 7, variabel yang signifikan di provinsi yang berdekatan cenderung sama. Hal ini menandakan adanya efek spasial yang sangat berpengaruh pada kematian ibu di setiap provinsi di Indonesia. Contohnya, pada provinsi Aceh dan Sumatera Utara variabel yang berpengaruh signifikan terhadap kematian ibu adalah sama yaitu variabel persentase persalinan ditolong tenaga kesehatan. 
Nilai AIC dan deviance dari model regresi Poisson dan model GWPR dapat dilihat dalam Tabel 6. Model GWPR secara bersama-sama memberikan nilai AIC dan deviance masing-masing sebesar 200,364 dan 35,889, sedangkan model regresi Poisson sebesar 225,720 dan 68,596. Nilainilai AIC dan deviance model GWPR lebih kecil dibandingkan model Poisson sehingga GWPR memodelkan kematian ibu lebih baik dibandingkan dengan regresi Poisson.

Tabel 6. Nilai AIC dan Deviance untuk Model Regresi Poisson dan GWPR Angka Kematian Ibu di Indonesia.

\begin{tabular}{ccc}
\hline Model Regresi & AIC & Deviance \\
\hline$(1)$ & $(2)$ & $(3)$ \\
\hline Regresi Poisson & 225,720 & 68,596 \\
GWPR KernelFixedGaussian & 200,364 & 35,889 \\
\hline
\end{tabular}

\section{SIMPULAN}

Model GWPR kernel fixed Gaussian memodelkan data kematian ibu di Indonesia lebih baik dibandingkan model regresi Poisson. Berdasarkan pemodelan GWPR untuk data kematian ibu di Indonesia menunjukkan variabel yang berpengaruh signifikan terhadap jumlah kematian ibu per 100.000 wanita usia 15 tahun ke atas adalah: (1) persentase persalinan ditolong tenaga kesehatan (X4) untuk Provinsi Aceh dan Sumatera Utara; (2) rasio sarana kesehatan per 100.000 penduduk (X1), rasio bidan per 100.000 penduduk (X2), dan persentase persalinan ditolong tenaga kesehatan(X4) untuk Provinsi Papua. Ketiga, rasio bidan per 100.000 penduduk (X2) dan persentase persalinan ditolong tenaga kesehatan (X4) untuk provinsi lainnya.

\section{REFERENSI}

Agresti, A. (2013).Categorical data analysis (Third Edition). New Jersey: John Wiley \& Sons, Inc. Azmi, A. I. (2014). Pemodelan geographically weighted Poisson regression semiparametric pada data kematian ibu tahun 2012 (Studi Kasus di Provinsi Jawa Timur dan Jawa Tengah). Jurusan Matematika FMIPA Universitas Brawijaya.

Badan Pusat Statistik. (2016). Sistem informasi rujukan statistik - view indikator. Diakses pada 19 Agustus 2016, 17:35 melalui http://sirusa.bps.go.id/index.php?r=indikator/view\&id=80

Cameron, A., C., \& Trivedi, P., K. (2013). Regression analysis of count data (Second Edition). New York: Cambridge University Press.

Fotheringham, A. S., Brunsdon, C., \& Charlton, M. (2002). Geographically weighted regression: the analysis of spatially varying relationships. John Wiley \& Sons Inc.

Harahap, H. A. (2015). Geographically weighted poisson regression untuk analisis jumlah kematian ibu di indonesia tahun 2011. Jakarta: Sekolah Tinggi Ilmu Statistik (Skripsi).

McCullagh, P., \& Nelder, J. A. (1989). Generalized linear models (Second Edition). London: Chapman \& Hall.

Nakaya, T., Brunsdon, C., Charlton, M., \& Fotheringham, A. S. (2005). Geographically weighted Poisson regression for disease association mapping. Statistics in Medicine, 24, 2695-2717. (doi:10.1002/sim.2129).

Neter, J., Wasserman, W., \& Kutner, M. H. (1983). Applied linear regression model. Illinois: Richard D. Irwin Inc. 
Novita, L., Salamah, M., \& Sutikno. (2012). Pemodelan maternal mortality di Jawa Timur dengan pendekatan geographically weighted poisson regression (GWPR). Diakses pada 19 Agustus 2016, 19:21 melalui http://digilib.its.ac.id/public/lTS-Undergraduate-17952-Paper-438473.pdf.

PBB. (2015). Transforming our world: the 2030 agenda for sustainable. PBB.

Qomariyah, N., Purnami, S. W., \& Pramono, M. S. (2013). Pemodelan faktor-faktor yang mempengaruhi jumlah kematian ibu di Jatim dengan pendekatan GWPR (Geographically Weighted Poisson Regression) Ditinjau dari Segi Fasilitas Kesehatan. JURNAL SAINS DAN SENI POMITS, 2337-3520.

Ramadhan, R,F. \& Kurniawan, R. (2016). Pemodelan data kematian bayi dengan geographically weighted negative binomial regression. Media Statistika, Vol. 9. No. 2, 95-106.

Rogerson, P. (2001). Statistical methods for geography. Sage.

Saefuddin, A., Saepudin, D., \& Kusumaningrum, D. (2013). Geographically weighted poisson regression (GWPR) for analyzing the malnutrition data in Java-Indonesia. ERSA conference papers. Vienna: European Regional Science Association.

Yasin, H. (2011). Pemilihan variabel pada model geographically weighted regression. Media Statistika Vol. 4 No. 2, 63-72. 
Lampiran 1. Hasil Pengujian Signifikansi Model AKI dengan GWPR.

\begin{tabular}{|c|c|}
\hline obs $=1$ & X-Coordinate $=96.9087$ \\
\hline $\begin{array}{l}\text { (Intercept) } \\
\times 1 \\
\times 2 \\
\times 4 \\
\times 5\end{array}$ & $\begin{array}{rrrr}\text { Coefficients } & \text { Std Error } & \text { pseudo-t } & \text { p-Value } \\
4.6884810 & 0.6505950 & 7.206451 & 0.0000 \\
0.5799014 & 0.4221696 & 1.373622 & 0.1696 \\
0.6460836 & 0.4147552 & 1.557747 & 0.1193 \\
-2.8163719 & 0.8895915 & -3.165916 & 0.0015 \\
-0.8223643 & 0.7417629 & -1.108662 & 0.2676\end{array}$ \\
\hline$\tilde{\mathrm{obs}}=2$ & 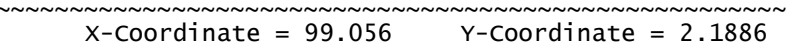 \\
\hline $\begin{array}{l}\text { (Intercept) } \\
\times 1 \\
\times 2 \\
\times 4 \\
\times 5\end{array}$ & $\begin{array}{rrrr}\text { Coefficients } & \text { Std Error } & \text { pseudo-t } & \text { p-value } \\
4.7438718 & 0.6465142 & 7.337615 & 0.0000 \\
0.4528744 & 0.4042793 & 1.120202 & 0.2626 \\
0.7027591 & 0.3936747 & 1.785126 & 0.0742 \\
-2.8913996 & 0.8216035 & -3.519215 & 0.0004 \\
-0.7500677 & 0.6582126 & -1.139552 & 0.2545\end{array}$ \\
\hline 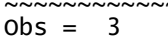 & 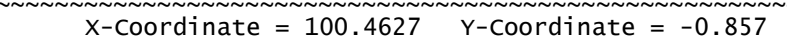 \\
\hline $\begin{array}{l}\text { (Intercept) } \\
\times 1 \\
\times 2 \\
\times 4 \\
\times 5\end{array}$ & $\begin{array}{rlrr}\text { Coefficients } & \text { Std Error } & \text { pseudo-t } & \text { p-value } \\
4.7708763 & 0.6440107 & 7.4080695 & 0.0000 \\
0.3253121 & 0.3873815 & 0.8397719 & 0.4010 \\
0.7658464 & 0.3692261 & 2.0741934 & 0.0381 \\
-2.8964135 & 0.7676373 & -3.7731538 & 0.0002 \\
-0.7272382 & 0.6046314 & -1.2027794 & 0.2291\end{array}$ \\
\hline  & 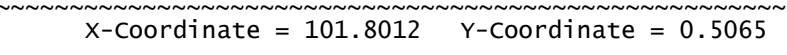 \\
\hline $\begin{array}{l}\text { (Intercept) } \\
\times 1 \\
\times 2 \\
\times 4 \\
\times 5\end{array}$ & $\begin{array}{rlrr}\text { Coefficients } & \text { Std Error } & \text { pseudo-t } & \text { p-value } \\
4.8067100 & 0.6425295 & 7.4809170 & 0.0000 \\
0.2681031 & 0.3801509 & 0.7052545 & 0.4807 \\
0.7988465 & 0.3614268 & 2.2102583 & 0.0271 \\
-2.9949954 & 0.7449213 & -4.0205529 & 0.0001 \\
-0.6319642 & 0.5777268 & -1.0938808 & 0.2740\end{array}$ \\
\hline 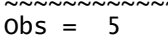 & $\begin{array}{l}\text { X-Coordinate }=102.7231 \quad \text { Y-Coordinate }=-1.6976\end{array}$ \\
\hline $\begin{array}{l}\text { (Intercept) } \\
\times 1 \\
\times 2 \\
\times 4 \\
\times 5\end{array}$ & $\begin{array}{rlrr}\text { Coefficients } & \text { Std Error } & \text { pseudo-t } & \text { p-value } \\
4.8091535 & 0.6402276 & 7.5116312 & 0.0000 \\
0.1640979 & 0.3679229 & 0.4460118 & 0.6556 \\
0.8579966 & 0.3407481 & 2.5179790 & 0.0118 \\
-2.9791361 & 0.7122615 & -4.1826439 & 0.0000 \\
-0.6136204 & 0.5509468 & -1.1137563 & 0.2654\end{array}$ \\
\hline$\tilde{\mathrm{Obs}}=\mathbf{6}$ & 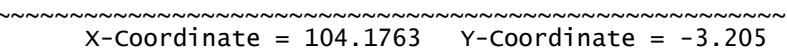 \\
\hline $\begin{array}{l}\text { (Intercept) } \\
\times 1 \\
\times 2 \\
\times 4 \\
\times 5\end{array}$ & $\begin{array}{rlrr}\text { Coefficients } & \text { Std Error } & \text { pseudo-t } & \text { p-value } \\
4.80930195 & 0.6372728 & 7.54669271 & 0.0000 \\
0.02694595 & 0.3542088 & 0.07607365 & 0.9394 \\
0.94316245 & 0.3156814 & 2.98770353 & 0.0028 \\
-2.98875729 & 0.6765537 & -4.41762041 & 0.0000 \\
-0.54953642 & 0.5217671 & -1.05322166 & 0.2922\end{array}$ \\
\hline 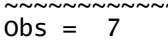 & X-Coordinate $=102.3858 \quad$ Y-Coordinate $=-3.5895$ \\
\hline $\begin{array}{l}\text { (Intercept) } \\
\times 1 \\
\times 2 \\
\times 4 \\
\times 5\end{array}$ & $\begin{array}{rlrr}\text { Coefficients } & \text { Std Error } & \text { pseudo-t } & \text { p-value } \\
4.7918974 & 0.6408392 & 7.4775352 & 0.0000 \\
0.1488604 & 0.3659861 & 0.4067378 & 0.6842 \\
0.8659497 & 0.3354396 & 2.5815367 & 0.0098 \\
-2.9174381 & 0.7104342 & -4.1065565 & 0.0000 \\
-0.6600173 & 0.5521218 & -1.1954197 & 0.2319\end{array}$ \\
\hline 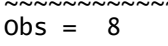 & X-Coordinate $=105.0206 \quad$ Y-Coordinate $=-4.9179$ \\
\hline $\begin{array}{l}\text { (Intercept) } \\
\times 1 \\
\times 2 \\
\times 4 \\
\times 5\end{array}$ & $\begin{array}{rlrr}\text { Coefficients } & \text { Std Error } & \text { pseudo-t } & \text { p-value } \\
4.79107933 & 0.6355543 & 7.5384259 & 0.0000 \\
-0.07610651 & 0.3455918 & -0.2202208 & 0.8257 \\
1.01095911 & 0.2971041 & 3.4027104 & 0.0007 \\
-2.96196212 & 0.6555405 & -4.5183513 & 0.0000 \\
-0.51948338 & 0.5066933 & -1.0252423 & 0.3052\end{array}$ \\
\hline
\end{tabular}


Lampiran 1. (lanjutan).

\begin{tabular}{|c|c|}
\hline obs $=9$ & $\mathrm{X}$-Coordinate $=106.5004 \quad \mathrm{Y}$-Coordinate $=-2.4343$ \\
\hline $\begin{array}{l}\text { (Intercept) } \\
\times 1 \\
\times 2 \\
\times 4 \\
\times 5\end{array}$ & $\begin{array}{rlrr}\text { Coefficients } & \text { Std Error } & \text { pseudo-t } & \text { p-value } \\
4.8092432 & 0.6328390 & 7.5994740 & 0.0000 \\
-0.1336132 & 0.3449964 & -0.3872888 & 0.6985 \\
1.0543818 & 0.2919430 & 3.6116014 & 0.0003 \\
-3.0562059 & 0.6414874 & -4.7642496 & 0.0000 \\
-0.4084888 & 0.4941934 & -0.8265767 & 0.4085\end{array}$ \\
\hline obs $=10$ & $\mathrm{X}$-Coordinate $=105.6218 \quad \mathrm{Y}$-Coordinate $=1.4741$ \\
\hline $\begin{array}{l}\text { (Intercept) } \\
\times 1 \\
\times 2 \\
\times 4 \\
\times 5\end{array}$ & $\begin{array}{rlrr}\text { Coefficients } & \text { Std Error } & \text { pseudo-t } & \text { p-Value } \\
4.86277274 & 0.6377607 & 7.62476121 & 0.0000 \\
0.01785669 & 0.3580957 & 0.04986569 & 0.9602 \\
0.95181713 & 0.3214234 & 2.96125694 & 0.0031 \\
-3.15785644 & 0.6754108 & -4.67546058 & 0.0000 \\
-0.41016655 & 0.5114013 & -0.80204448 & 0.4225\end{array}$ \\
\hline$\tilde{\mathrm{Ob} \sim \sim \sim \sim \sim \sim \sim \sim} \sim \tilde{11}$ & X-Coordinate $=106.8277 \quad$ Y-Coordinate $=-6.1877$ \\
\hline $\begin{array}{l}\text { (Intercept) } \\
\times 1 \\
\times 2 \\
\times 4 \\
\times 5\end{array}$ & $\begin{array}{rlrr}\text { Coefficients } & \text { Std Error } & \text { pseudo-t } & \text { p-value } \\
4.7551572 & 0.6318224 & 7.5260975 & 0.0000 \\
-0.2449155 & 0.3369943 & -0.7267644 & 0.4674 \\
1.1317186 & 0.2727088 & 4.1499155 & 0.0000 \\
-2.9495725 & 0.6252493 & -4.7174342 & 0.0000 \\
-0.4263275 & 0.4864129 & -0.8764723 & 0.3808\end{array}$ \\
\hline 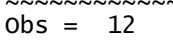 & X-Coordinate $=107.6018 \quad$ Y-Coordinate $=-6.9205$ \\
\hline $\begin{array}{l}\text { (Intercept) } \\
\times 1 \\
\times 2 \\
\times 4 \\
\times 5\end{array}$ & $\begin{array}{rlrr}\text { Coefficients } & \text { Std Error } & \text { pseudo-t } & \text { p-value } \\
4.7300137 & 0.6302592 & 7.5048702 & 0.0000 \\
-0.3192055 & 0.3352439 & -0.9521589 & 0.3410 \\
1.1884564 & 0.2642364 & 4.4977011 & 0.0000 \\
-2.9312526 & 0.6141807 & -4.7726223 & 0.0000 \\
-0.3898642 & 0.4804181 & -0.8115102 & 0.4171\end{array}$ \\
\hline 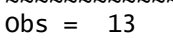 & X-Coordinate $=110.2045 \quad$ Y-Coordinate $=-7.2578$ \\
\hline $\begin{array}{l}\text { (Intercept) } \\
\times 1 \\
\times 2 \\
\times 4 \\
\times 5\end{array}$ & $\begin{array}{rlrr}\text { Coefficients } & \text { Std Error } & \text { pseudo-t } & \text { p-value } \\
4.6530717 & 0.6233834 & 7.464222 & 0.0000 \\
-0.4906383 & 0.3401444 & -1.442441 & 0.1492 \\
1.3431508 & 0.2558596 & 5.249562 & 0.0000 \\
-2.9031708 & 0.5862608 & -4.952012 & 0.0000 \\
-0.2746608 & 0.4724941 & -0.581300 & 0.5610\end{array}$ \\
\hline obs $=14$ & $\mathrm{X}$-Coordinate $=110.4478 \quad \mathrm{Y}$-Coordinate $=-7.8937$ \\
\hline $\begin{array}{l}\text { (Intercept) } \\
\times 1 \\
\times 2 \\
\times 4 \\
\times 5\end{array}$ & $\begin{array}{rlrr}\text { Coefficients } & \text { Std Error } & \text { pseudo-t } & \text { p-value } \\
4.6376810 & 0.6228070 & 7.4464175 & 0.0000 \\
-0.5158729 & 0.3407700 & -1.5138447 & 0.1301 \\
1.3653572 & 0.2557317 & 5.3390227 & 0.0000 \\
-2.8837548 & 0.5835984 & -4.9413341 & 0.0000 \\
-0.2705299 & 0.4720297 & -0.5731205 & 0.5666\end{array}$ \\
\hline 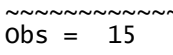 & X-Coordinate $=112.7309 \quad$ Y-Coordinate $=-7.72$ \\
\hline $\begin{array}{l}\text { (Intercept) } \\
\times 1 \\
\times 2 \\
\times 4 \\
\times 5\end{array}$ & $\begin{array}{rlrr}\text { Coefficients } & \text { Std Error } & \text { pseudo-t } & \text { p-value } \\
4.5643287 & 0.6151656 & 7.4196751 & 0.0000 \\
-0.5918626 & 0.3528916 & -1.6771795 & 0.0935 \\
1.4793699 & 0.2672255 & 5.5360357 & 0.0000 \\
-2.8503030 & 0.5631808 & -5.0610797 & 0.0000 \\
-0.2185054 & 0.4753981 & -0.4596261 & 0.6458\end{array}$ \\
\hline obs $=16$ & $\mathrm{x}$-Coordinate $=106.1097$ \\
\hline $\begin{array}{l}\text { (Intercept) } \\
\times 1 \\
\times 2 \\
\times 4 \\
\times 5\end{array}$ & $\begin{array}{rlrr}\text { Coefficients } & \text { Std Error } & \text { pseudo-t } & \text { p-value } \\
4.7631680 & 0.6335902 & 7.5177420 & 0.0000 \\
-0.1964654 & 0.3383200 & -0.5807087 & 0.5614 \\
1.0948300 & 0.2784043 & 3.9325183 & 0.0001 \\
-2.9359747 & 0.6347608 & -4.6253243 & 0.0000 \\
-0.4701619 & 0.4924131 & -0.9548119 & 0.3397\end{array}$ \\
\hline
\end{tabular}


Lampiran 1. (lanjutan).

\begin{tabular}{|c|c|c|}
\hline obs $=17$ & $\mathrm{X}$-Coordinate $=115.132 \mathrm{Y}$-Coo & rdinate $=-8.3675$ \\
\hline $\begin{array}{l}\text { (Intercept) } \\
\times 1 \\
\times 2 \\
\times 4 \\
\times 5\end{array}$ & $\begin{array}{rlr}\text { Coefficients } & \text { Std Error } & \text { pseudo-t } \\
4.4823888 & 0.6080992 & 7.3711477 \\
-0.6079324 & 0.3690913 & -1.6471057 \\
1.5870455 & 0.2914377 & 5.4455744 \\
-2.7951597 & 0.5417045 & -5.1599348 \\
-0.2272359 & 0.4823109 & -0.4711399\end{array}$ & $\begin{array}{r}p-\text { value } \\
0.0000 \\
0.0995 \\
0.0000 \\
0.0000 \\
0.6375\end{array}$ \\
\hline 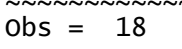 & $\mathrm{x}$-Coordinate $=117.5133$ & Y-Coordinate $=-8.6067$ \\
\hline $\begin{array}{l}\text { (Intercept) } \\
\times 1 \\
\times 2 \\
\times 4 \\
\times 5\end{array}$ & $\begin{array}{rrr}\text { Coefficients } & \text { Std Error } & \text { pseudo-t } \\
4.4032341 & 0.6091609 & 7.2283596 \\
-0.5337270 & 0.3904870 & -1.3668239 \\
1.6714102 & 0.3223179 & 5.1855948 \\
-2.7502428 & 0.5226933 & -5.2616765 \\
-0.2887167 & 0.4914003 & -0.5875388\end{array}$ & $\begin{array}{r}p-\text { value } \\
0.0000 \\
0.1717 \\
0.0000 \\
0.0000 \\
0.5568\end{array}$ \\
\hline $\begin{array}{l}\sim \sim \sim \sim \sim \sim \sim \sim \sim \\
\text { obs }=19\end{array}$ & 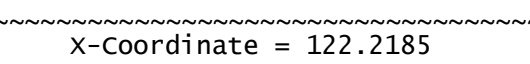 & 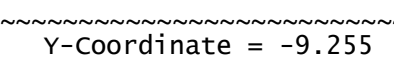 \\
\hline $\begin{array}{l}\text { (Intercept) } \\
\times 1 \\
\times 2 \\
\times 4 \\
\times 5\end{array}$ & $\begin{array}{rlr}\text { Coefficients } & \text { Std Error } & \text { pseudo-t } \\
4.1880381 & 0.6595837 & 6.3495172 \\
-0.1830435 & 0.4554153 & -0.4019265 \\
1.8147977 & 0.3954891 & 4.5887424 \\
-2.6338907 & 0.5116962 & -5.1473723 \\
-0.5185118 & 0.5153110 & -1.0062113\end{array}$ & $\begin{array}{r}p-\text { value } \\
0.0000 \\
0.6877 \\
0.0000 \\
0.0000 \\
0.3143\end{array}$ \\
\hline$\tilde{\mathrm{Obs}}=20$ & X-Coordinate $=111.1198$ & Y-Coordinate $=-0.0879$ \\
\hline $\begin{array}{l}\text { (Intercept) } \\
\times 1 \\
\times 2 \\
\times 4 \\
\times 5\end{array}$ & $\begin{array}{rrr}\text { Coefficients Std Error } & \text { pseudo-t } \\
4.7254101 & 0.6220925 & 7.5959928 \\
-0.3942080 & 0.3562261 & -1.1066230 \\
1.2912170 & 0.2684698 & 4.8095420 \\
-3.0848156 & 0.5960563 & -5.1753765 \\
-0.1940107 & 0.4798232 & -0.4043378\end{array}$ & $\begin{array}{r}p-\text { value } \\
0.0000 \\
0.2685 \\
0.0000 \\
0.0000 \\
0.6860\end{array}$ \\
\hline$\tilde{\text { Obs } \sim \sim \sim \sim \sim \sim \sim \sim \sim n ~}$ & X-Coordinate $=113.4164$ & Y-Coordinate $=-1.6004$ \\
\hline $\begin{array}{l}\text { (Intercept) } \\
\times 1 \\
\times 2 \\
\times 4 \\
\times 5\end{array}$ & $\begin{array}{rlr}\text { Coefficients Std Error } & \text { pseudo-t } \\
4.6039987 & 0.6152180 & 7.4835238 \\
-0.5029617 & 0.3664445 & -1.3725455 \\
1.4453413 & 0.2725373 & 5.3032791 \\
-2.9752169 & 0.5674645 & -5.2430008 \\
-0.1709865 & 0.4837674 & -0.3534478\end{array}$ & $\begin{array}{l}p-\text { va } 7 \text { ue } \\
0.0000 \\
0.1699 \\
0.0000 \\
0.0000 \\
0.7238\end{array}$ \\
\hline$\tilde{\text { Obs }}=22$ & X-Coordinate $=115.4339$ & 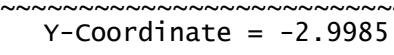 \\
\hline $\begin{array}{l}\text { (Intercept) } \\
\times 1 \\
\times 2 \\
\times 4 \\
\times 5\end{array}$ & $\begin{array}{rlr}\text { Coefficients } & \text { Std Error } & \text { pseudo-t } \\
4.4992208 & 0.6116267 & 7.3561547 \\
-0.5280031 & 0.3787615 & -1.3940253 \\
1.5624851 & 0.2914485 & 5.3611027 \\
-2.8843611 & 0.5450609 & -5.2918144 \\
-0.1937388 & 0.4901297 & -0.3952806\end{array}$ & $\begin{array}{r}p-\text { va } 7 \text { ue } \\
0.0000 \\
0.1633 \\
0.0000 \\
0.0000 \\
0.6926\end{array}$ \\
\hline 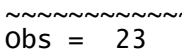 & $\mathrm{X}$-Coordinate $=116.3812$ & Y-Coordinate $=1.3311$ \\
\hline $\begin{array}{l}\text { (Intercept) } \\
\times 1 \\
\times 2 \\
\times 4 \\
\times 5\end{array}$ & $\begin{array}{rlr}\text { Coefficients Std Error } & \text { pseudo-t } \\
4.4893483 & 0.6148352 & 7.301710 \\
-0.4573969 & 0.3993235 & -1.145430 \\
1.5741309 & 0.3013868 & 5.222959 \\
-2.9383611 & 0.5479160 & -5.362795 \\
-0.1811515 & 0.5003632 & -0.362040\end{array}$ & $\begin{array}{l}p-\text { value } \\
0.0000 \\
0.2520 \\
0.0000 \\
0.0000 \\
0.7173\end{array}$ \\
\hline$\tilde{\text { Obs }}=24$ & $\mathrm{X}$-Coordinate $=124.5153$ & Y-Coordinate $=1.2514$ \\
\hline $\begin{array}{l}\text { (Intercept) } \\
\times 1 \\
\times 2 \\
\times 4 \\
\times 5\end{array}$ & $\begin{array}{rrr}\text { Coefficients } & \text { Std Error } & \text { pseudo-t } \\
3.9093084 & 0.7073331 & 5.5268282 \\
0.1976972 & 0.5250465 & 0.3765328 \\
1.9584459 & 0.4281904 & 4.5737732 \\
-2.6366497 & 0.5329506 & -4.9472685 \\
-0.5685903 & 0.5512114 & -1.0315286\end{array}$ & $\begin{array}{r}p-\text { value } \\
0.0000 \\
0.7065 \\
0.0000 \\
0.0000 \\
0.3023\end{array}$ \\
\hline
\end{tabular}


Lampiran 1. (lanjutan).

\begin{tabular}{|c|c|c|}
\hline obs $=25$ & $\mathrm{X}$-Coordinate $=121.196$ & $\mathrm{Y}$-Coordinate $=-0.9801$ \\
\hline $\begin{array}{l}\text { (Intercept) } \\
\times 1 \\
\times 2 \\
\times 4 \\
\times 5\end{array}$ & $\begin{array}{rrr}\text { Coefficients } & \text { Std Error } & \text { pseudo-t } \\
4.1880293 & 0.6510736 & 6.4324976 \\
-0.1791281 & 0.4562318 & -0.3926252 \\
1.8081511 & 0.3746492 & 4.8262510 \\
-2.7420388 & 0.5184938 & -5.2884693 \\
-0.4008284 & 0.5240532 & -0.7648620\end{array}$ & $\begin{array}{l}p-\text { va7ue } \\
0.0000 \\
0.6946 \\
0.0000 \\
0.0000 \\
0.4444\end{array}$ \\
\hline 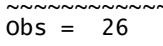 & X-Coordinate $=120.1646$ & 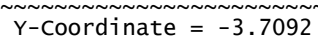 \\
\hline $\begin{array}{l}\text { (Intercept) } \\
\times 1 \\
\times 2 \\
\times 4 \\
\times 5\end{array}$ & $\begin{array}{rrr}\text { Coefficients } & \text { Std Error } & \text { pseudo-t } \\
4.2640534 & 0.6353635 & 6.7112032 \\
-0.2971880 & 0.4323755 & -0.6873377 \\
1.7634373 & 0.3593314 & 4.9075509 \\
-2.7459915 & 0.5154640 & -5.3272229 \\
-0.3675322 & 0.5129832 & -0.7164604\end{array}$ & $\begin{array}{r}p-\text { value } \\
0.0000 \\
0.4919 \\
0.0000 \\
0.0000 \\
0.4737\end{array}$ \\
\hline 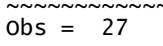 & X-Coordinate $=122.078 \%$ & 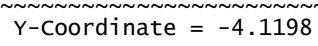 \\
\hline $\begin{array}{l}\text { (Intercept) } \\
\text { x1 } \\
\text { x2 } \\
\text { x4 } \\
\times 5\end{array}$ & $\begin{array}{rlr}\text { Coefficients } & \text { Std Error } & \text { pseudo-t } \\
4.1444352 & 0.6621159 & 6.2593805 \\
-0.1241783 & 0.4632378 & -0.2680661 \\
1.8355183 & 0.3907819 & 4.6970395 \\
-2.6835406 & 0.5159906 & -5.2007547 \\
-0.4723586 & 0.5242472 & -0.9010226\end{array}$ & $\begin{array}{r}\mathrm{p}-\mathrm{va} \text { a ue } \\
0.0000 \\
0.7886 \\
0.0000 \\
0.0000 \\
0.3676\end{array}$ \\
\hline 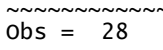 & 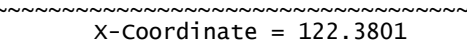 & 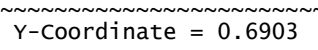 \\
\hline $\begin{array}{l}\text { (Intercept) } \\
\times 1 \\
\times 2 \\
\times 4 \\
\times 5\end{array}$ & $\begin{array}{rlr}\text { Coefficients } & \text { Std Error } & \text { pseudo-t } \\
4.09365785 & 0.6700594 & 6.10939555 \\
-0.04762538 & 0.4823631 & -0.09873346 \\
1.86258137 & 0.3933601 & 4.73505435 \\
-2.71562302 & 0.5225653 & -5.19671494 \\
-0.45344575 & 0.5348373 & -0.84781990\end{array}$ & $\begin{array}{lr}\mathrm{t} & \mathrm{p}-\mathrm{Va} \text {-vie } \\
5 & 0.0000 \\
6 & 0.9213 \\
5 & 0.0000 \\
4 & 0.0000 \\
0 & 0.3965\end{array}$ \\
\hline$\tilde{\mathrm{Obs}}=29$ & X-Coordinate = 119.338 & 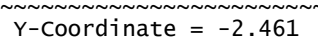 \\
\hline $\begin{array}{l}\text { (Intercept) } \\
\times 1 \\
\times 2 \\
\times 4 \\
\times 5\end{array}$ & $\begin{array}{rlr}\text { Coefficients } & \text { Std Error } & \text { pseudo-t } \\
4.3085948 & 0.6279200 & 6.8616941 \\
-0.3484775 & 0.4231643 & -0.8235039 \\
1.7302328 & 0.3455525 & 5.0071483 \\
-2.7838650 & 0.5193824 & -5.3599521 \\
-0.3181432 & 0.5102916 & -0.6234537\end{array}$ & $\begin{array}{l}\mathrm{p}-\mathrm{va} \text { vae } \\
0.0000 \\
0.4102 \\
0.0000 \\
0.0000 \\
0.5330\end{array}$ \\
\hline 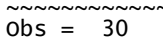 & X-Coordinate $=129.8423$ &  \\
\hline $\begin{array}{l}\text { (Intercept) } \\
\times 1 \\
\times 2 \\
\times 4 \\
\times 5\end{array}$ & $\begin{array}{rrr}\text { Coefficients } & \text { std Error } & \text { pseudo-t p p } \\
3.4914383 & 0.8040614 & 4.342253 \\
0.7884580 & 0.6036415 & 1.306169 \\
2.0996306 & 0.5139827 & 4.085022 \\
-2.3792815 & 0.5729899 & -4.152397 \\
-0.8630256 & 0.5790916 & -1.490309\end{array}$ & $\begin{array}{l}p-\text { value } \\
0.0000 \\
0.1915 \\
0.0000 \\
0.0000 \\
0.1361\end{array}$ \\
\hline 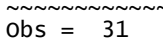 & X-Coordinate $=127.5487$ & Y-Coordinate $=0.2058$ \\
\hline $\begin{array}{l}\text { (Intercept) } \\
\times 1 \\
\times 2 \\
\times 4 \\
\times 5\end{array}$ & $\begin{array}{rrr}\text { Coefficients } & \text { Std Error } & \text { pseudo-t } \\
3.6341316 & 0.7617837 & 4.7705555 \\
0.5656514 & 0.5802553 & 0.9748319 \\
2.0743846 & 0.4760605 & 4.3573974 \\
-2.5044134 & 0.5559589 & -4.5046738 \\
-0.7309145 & 0.5723417 & -1.2770597\end{array}$ & $\begin{array}{r}p-\text { value } \\
0.0000 \\
0.3296 \\
0.0000 \\
0.0000 \\
0.2016\end{array}$ \\
\hline 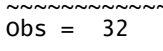 & X-Coordinate $=138.6771$ & Y-Coordinate $=-4.6485$ \\
\hline $\begin{array}{l}\text { (Intercept) } \\
\times 1 \\
\times 2 \\
\times 4 \\
\times 5\end{array}$ & $\begin{array}{rrr}\text { Coefficients } & \text { Std Error } & \text { pseudo-t } \\
2.789309 & 0.8956160 & 3.114403 \\
1.777309 & 0.8294458 & 2.142767 \\
2.237726 & 0.6267115 & 3.570584 \\
-2.124191 & 0.6414141 & -3.311731 \\
-1.022132 & 0.6573040 & -1.555037\end{array}$ & $\begin{array}{l}p-\text { value } \\
0.0018 \\
0.0321 \\
0.0004 \\
0.0009 \\
0.1199\end{array}$ \\
\hline 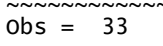 & 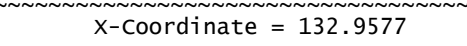 & Y-Coordinate $=-2.0304$ \\
\hline $\begin{array}{l}\text { (Intercept) } \\
\times 1 \\
\times 2 \\
\times 4 \\
\times 5\end{array}$ & $\begin{array}{rrr}\text { Coefficients } & \text { Std Error } & \text { pseudo-t } \\
3.1664868 & 0.8403841 & 3.767904 \\
1.2040247 & 0.6785708 & 1.774354 \\
2.2089444 & 0.5524484 & 3.998463 \\
-2.2864426 & 0.6021804 & -3.796939 \\
-0.9355101 & 0.6102882 & -1.532899\end{array}$ & $\begin{array}{l}p-\text { value } \\
0.0002 \\
0.0760 \\
0.0001 \\
0.0001 \\
0.1253\end{array}$ \\
\hline
\end{tabular}

